\title{
The Level of Integrated Reporting Alignment with the IIRC Framework: Evidence from South Africa
}

\author{
Arcangelo Marrone ${ }^{1} \&$ Lara Oliva $^{1}$ \\ ${ }^{1}$ Department of Economics and Management, University LUM Jean Monnet, Italy \\ Correspondence: Arcangelo Marrone, Department of Economics and Management, University LUM Jean Monnet, \\ Casamassima (BA), Italy. E-mail: marrone@lum.it
}

Received: November 22, 2019

Accepted: December 10, 2019

Online Published: December 13, 2019

doi:10.5539/ijbm.v15n1p99

URL: https://doi.org/10.5539/ijbm.v15n1p99

\begin{abstract}
In recent years, corporate disclosure policies have undergone important changes due mainly to greater requests from stakeholders and the presence of limited resources. Companies are forced to rethink their disclosure strategies and the way they communicate to the outside, in order to increase transparency and meet the needs of their stakeholders. In this context, Integrated Reporting (IR), developed by the International Integrated Reporting Council (IIRC), represents a new way to provide, in a single document, interconnected information on strategies, risks, performance, governance and future prospects. In the development process of this reporting tool, South Africa played an important role. Therefore, this study aims to analyse the level of alignment of integrated reports with the IIRC framework in the South African contest. The results show first of all that South African companies provide integrated reports with high levels of alignment with the IIRC framework. Secondly, the analysis of the determinants shows how firm size, firm profitability and financial leverage positively affect the level of compliance of the integrated reports with the IIRC requirements.
\end{abstract}

Keywords: integrated reporting, compliance, IIRC, disclosure, South Africa

\section{Introduction}

In recent years, corporate disclosure policies have undergone important changes due mainly to greater requests from stakeholders and the presence of limited resources. Companies are forced to rethink their disclosure strategies and the way they communicate to the outside, in order to increase transparency and meet the needs of their stakeholders. In this context, the integration of financial and non-financial information, with a consequent holistic view of the business activity, is becoming increasingly popular (Jensen \& Berg, 2012; Fifka, 2013).

Integrated reporting (IR), developed by the International Integrated Reporting Council (IIRC), represents the ultimate frontier of corporate disclosure and is able to provide information relating to strategy, risks, performance, governance and future prospects in a single document (IIRC, 2013). One of the key principles of integrated reporting is represented by the integrated thinking that, according to the IIRC (2013) is "the active consideration by an organisation of the relationships between its various operating and functional units and the capitals that the organisation uses or affects. Integrated thinking leads to integrated decision making and actions that consider the creation of value over the short, medium, and long term". Therefore, according to Eccles \& Krzus (2010), an integrated report provides information on how the company creates and maintains value. This is mainly due to the attention that integrated reporting devotes to intangibles and intellectual capital (Vitolla et al., 2019a). Therefore, integrated reporting aims, firstly, to facilitate the investment decisions of capital providers and, secondly, to provide information to all other categories of stakeholders (IIRC, 2013).

In this context, South Africa is a pioneer of integrated reporting, being the first country in the world to adopt this disclosure tool (Ernst \& Young, 2012; Vitolla et al., 2018). Already in 2002, the Johannesburg Earth Summit had assigned an important value to corporate social responsibility, defining some points that companies should follow to promote sustainable development (Lambert, 2005). Subsequently, the Johannesburg Securities Exchange (JSE) made the publication of an integrated report a requirement for listed companies, transforming South Africa into a leading country in disclosure policies (SAICA, 2013). This circumstance is only a starting point, since from 2010 to today, attention to integrated reporting has grown more and more throughout the world.

This is mainly due to the numerous benefits related to integrated reporting, already highlighted by a large part of 
the literature (Vitolla \& Raimo, 2018; Vitolla et al., 2019b; Vitolla et al., 2019c).

However, it is not yet clear whether these benefits are related to the simple adoption of the integrated reporting or the drafting of the report in compliance with the content and guiding principles defined by the IIRC. Greater alignment with the IIRC framework could in fact allow for greater standardization of content and, consequently, greater understanding of corporate dynamics for investors and all stakeholders in general. Furthermore, greater compliance with the IIRC framework could make it easier to search for some key content, made complex by the excessive length of the integrated reports. Therefore, the level of alignment is particularly important and differs from the simple adoption of the integrated reporting, from the quality and quantity of information contained in the integrated reports. However, despite the considerable importance of this element, the level of compliance of the integrated reports with the IIRC framework is still little explored by the literature. This work aims at the important goal of bridging this gap, exploring the determinants of the compliance level of South African companies' reports with the content and guiding principles defined by the IIRC. The analysis of the determinants of the alignment level is fundamental, since they could be different compared to the antecedents of the integrated reporting adoption and quality. The choice of South Africa is then connected to the pioneering role that this country has played in the implementation of this instrument. The regulatory obligation in the field of integrated reporting makes interesting the analysis of the level of alignment of the integrated reports with the IIRC framework in the South African context. A low level of alignment with the IIRC framework could in fact be synonymous with a mere formal adoption, connected only to a regulatory obligation present in South Africa, and not to the presence of an adequate level of integrated thinking that represents one of the core elements of the integrated reporting.

The remainder of this article is organized as follows. Section 2 analyses the background of this work. Section 3 introduces the hypotheses while section 4 describes the research methodology. Section 5 presents the results. Finally, section 6 discusses the results and draws conclusions.

\section{Background: South African Context}

In the last twenty years, South African companies, in line with international trends, have paid more and more attention to social and environmental dynamics (Wingard \& Vorster, 2001; Sonnenberg \& Hamann, 2006; Rensburg \& Botha, 2013). Furthermore, South Africa has played a particularly important role in the movement towards corporate social responsibility, non-financial disclosure and integrated reporting (Clayton et al., 2015). These circumstances led South Africa, in the 1990s and 2000s, to receive important international recognition both for the results achieved in terms of corporate governance and for legislative and regulatory requirements (Bezuidenhout et al., 2007; Eccles et al., 2012; GRI, 2013). The presence of social and environmental regulations and the interest in responsible investments have long made South Africa a leading nation in terms of sustainability reporting (Clayton et al., 2015). Attention to integrated reporting has also encouraged the growth of quality and quantity of information disclosed on sustainability issues (GRI, 2013).

South Africa's leadership role in the field of non-financial disclosure is connected to the country's political history and to the transition from apartheid to multi-racial democracy (Bezuidenhout et al., 2007). During the apartheid period, the fear of sanctions and divestments has prompted many companies operating in South Africa to respond with voluntary initiatives, such as the Sullivan Principles (Bezuidenhout et al., 2007; Clayton et al., 2015). These principles represented a code of conduct, established for the Unites Stated multinationals with affiliates in South Africa.

In the early 1990s, South Africa embarked on a path towards introducing new corporate governance policies (Eccles et al., 2012). In 1992, in the midst of an economic and political confusion of the country, the Institute of Directors in Southern Africa (IoDSA) commissioned the King Committee.The objective of this body was to promote the highest standards of corporate governance and to build a society based on a revaluation of values following the conclusion of the apartheid period and the cancellation of international sanctions (Schulschenk, 2012; Eccles et al., 2012; Clayton et al., 2015).

The King Committee in 1994 published the King I, the first King Report on Corporate disclosure. It regulated some financial aspects and above all emphasized the importance of stakeholder inclusiveness. In light of the entry into a new democracy, the regulation of these aspects represented a very important element for the country (Schulschenk, 2012; Eccles et al., 2012). King I was a voluntary document, however, in 1995, the JSE took over the core principles of King I and turned them into a listing requirement based on the "comply or explain". This circumstance represents a fundamental step in the evolutionary process of the country's corporate governance, as the JSE has greatly enhanced the importance of the principles of the King I (Schulschenk, 2012; Eccles et al., 2012; Clayton et al., 2015).

The World Summit on Sustainable Development in Johannesburg in 2002, further raised awareness of the need for 
sustainable development (Eccles et al., 2012). Therefore, in the same year, the King Committee was again convened and the King II was issued. The basic principle of this report is that "there is a move away from the single bottom line to a triple bottom line, which embraces the economic, environmental and social aspects of a company's activities" (IoDSA, 2002, p. 9). In this code, sustainability reporting has found space, representing a new fundamental principle in South Africa (IoDSA, 2002; Marx \& Van Der Watt, 2011; Schulschenk, 2012; Eccles et al., 2012; Clayton et al., 2015). Furthermore, this code included new sections on risk management and corporate boards (Berwick, 2007; Rensburg \& Botha, 2014).

After a few years, in 2009, the King Committee published the King III. This document suggested that companies provide information on sustainability, governance and strategy in an integrated manner (Rensburg \& Botha, 2014; Clayton et al., 2015). King III argued that strategy, performance, risks and sustainability were inseparable elements (Rensburg \& Botha, 2014). Therefore, for the first time a document required companies to disclose an integrated report (SAICA, 2013). The introduction of the concept of integrated report has represented a fundamental change and an evolution of corporate disclosure both nationally and internationally. The King III was again validated by the JSE and led South African companies to switch to the integrated report between 2010 and 2011 (SAICA, 2012).

In 2010, the Integrated Reporting Committee of South Africa (IRCSA) was introduced in the country. This body had the objective of developing guidelines for the development of integrated reports. In the following year, the IRCSA published a document entitled "Framework for Integrated Reporting and the Integrated Report: Discussion Paper" which contained the first guidelines for the preparation of an integrated report (SAICA, 2012).

This document has received worldwide approval and the IIRC has taken inspiration from it to forge its international guidelines, contained in the document "Towards Integrated Reporting communicating value in the 21 st century ", published in 2011. Therefore, although in the following years the King IV was also published in South Africa, it is clear that the King III has already inspired the creation of the IIRC and the $<$ IR $>$ framework. In light of this, it is clear that South Africa is the pioneer of integrated reporting. This circumstance makes it interesting to analyse the integrated reports of South African companies in order to assess the level of compliance with the IIRC framework. Despite the fundamental role played by South Africa in integrated reporting policies and the considerable importance of the concept of alignment, there are no contributions that have analysed the compliance level of the integrated reports of South African companies with the IIRC framework. This study aims to fill this important gap, investigating the level of alignment of the integrated reports with the IIRC requirements and its determinants in the South African contest.

\section{Hypothesis Development}

In the literature, the investigations relating to the level of alignment of the integrated reports with the IIRC framework are still lacking. A first scoreboard to measure the level of compliance was defined by Marrone \& Oliva (2019). However, more effort is needed to define the factors able to influence the level of alignment of the integrated reports with the IIRC framework. This work focuses on three financial determinants: size (in financial terms), profitability and financial leverage.

The literature agrees on the positive effects of the firm dimension on non-financial disclosure (Khan, 2010; Andrikopoulos et al., 2014; Frías-Aceituno et al., 2014; Sharif \& Rashid, 2014; Sierra-García et al., 2015; Bhasin et al., 2015; Abdullah et al., 2015; Marrone \& Oliva, 2019).

Companies that do not respect the social contract, according to the perspective related to the public pressure of legitimacy theory, risk the intrusion of the government in their business activity (Reverte, 2009). Furthermore, larger companies are subject to greater public control (Watts \& Zimmerman, 1986). This circumstance is connected to the greater pressures that larger companies receive from stakeholders (Vitolla et al., 2019d) and to the greater visibility they enjoy (Dowling \& Pfeffer, 1975). Larger companies have a greater impact on the local community and therefore have a greater number of stakeholders and greater pressures (Hackston \& Milne, 1996; Knox et al., 2005). Non-financial disclosure therefore allows larger companies to reduce the risk of government interference, to mitigate the pressures of stakeholders and to lower political costs (Adams et al., 1998; Clarke \& Gibson-Sweet, 1999; Gray et al., 1995; Ness \& Mirza, 1991). Integrated reporting offers large companies a tool to meet the needs of stakeholders, to reduce the risks of government interference and to mitigate pressures. However, for this to happen an adequate level of compliance of the integrated report with the IIRC framework is required (Marrone \& Oliva, 2019). In fact, a greater alignment allows a greater standardization of the contents improving the readability and increasing the comprehensibility of the integrated reports by the stakeholders. Furthermore, a greater compliance with the framework allows a comparison of the integrated reports of different firms and therefore favours the understanding of the different business dynamics. Finally, greater alignment simplifies the 
search for specific content within integrated reports. Such circumstances, meeting the needs of governments and stakeholders in general, reduce the pressures that companies receive and mitigate the risks of government interference, which represent particularly critical points for larger companies. Therefore, in light of this, it is possible to formulate the following hypothesis:

H1: Firm size is positively associated with integrated reporting alignment with the IIRC framework

The literature agrees on the positive relationship existing between firm profitability and corporate social responsibility (Cerf, 1961; Kahl \& Belkaoui, 1981; Singhvi \& Desai, 1971; Wallace \& Naser, 1995). This evidence can be explained by the fact that greater profitability allows companies to spend part of their monetary resources on activities related to sustainability (Sharif \& Rashid, 2014). Attention to corporate social responsibility activities drives firms to provide non-financial information. In fact, disclosure represents a means for profitable companies to make their performance known to stakeholders (Malone et al. 1993; Udayasankar, 2008; Siregar \& Bachtiar, 2010). Furthermore, increased profitability leads companies to provide more information to demonstrate their ability to maximize shareholder value (Singhvi \& Desai, 1971). The most profitable companies could also choose to disclose more information to promote a positive image (Sharif \& Rashid, 2014) and to distinguish their performance from those of less-successful firms (Frías-Aceituno et al., 2014). In the integrated reporting context, for this to happen an adequate level of compliance of the integrated report with the IIRC framework is required. In fact, only through an adequate level of compliance with the IIRC framework is it possible to allow a comparison between the integrated reports of the different companies, and therefore, show the difference between the performances of the most successful companies compared to the less-successful ones. Moreover, greater compliance, facilitating the search for key content, favours the promotion of a positive image of the most profitable companies. Therefore, in light of this, it is possible to formulate the following hypothesis:

$\mathrm{H} 2$ : Firm profitability is positively associated with integrated reporting alignment with the IIRC framework

The literature agrees on the positive effect of financial leverage on non-financial disclosure (Sharif \& Rashid, 2014; Andrikopoulos et al., 2014). A greater degree of financial leverage implies greater monitoring costs for companies (Jensen \& Meckling, 1976). In this regard, the disclosure represents a means for the company to demonstrate to its debtors the ability to fulfil financial obligations. A greater degree of financial leverage is, in fact, linked to an increase in the risk of bankruptcy for creditors and investors (Andrikopoulos et al., 2014). Therefore, for the most indebted companies, disclosure represents an even more important element as it represents a means to mitigate risks and show the ability to fulfil financial obligations. In the integrated reporting context, for this to happen, an adequate level of compliance of the integrated report with the IIRC framework is required. In fact, a greater alignment allows a greater standardization of the contents improving the readability and increasing the comprehensibility of the integrated reports by the stakeholders. Furthermore, greater compliance, facilitating the search for key content, allows investors and creditors to find the financial and non-financial information they need more quickly and easily. Therefore, in light of this, it is possible to formulate the following hypothesis:

H3: Financial leverage is positively associated with integrated reporting alignment with the IIRC framework

\section{Methodology}

\subsection{Sample}

The sample of this work is composed of 65 South African companies that publish an integrated report following the framework developed by the IIRC. Following Raimo et al. (2019), the integrated reports were selected from the " $<\mathrm{IR}>$ Reporters" and "Leading Practices" sections of the IIRC website. In this way, we can be sure that the reports are compiled in compliance with the IIRC framework. The choice of reports was random. The only criterion selected is the presence in South Africa of the general headquarters of the companies. The firms in the sample, in fact, are differentiated in terms of industry and size. The 2017 integrated reports were analysed in our work.

\subsection{Variables and Model Specification}

The level of alignment with the IIRC framework (IRAL) represents the dependent variable of this work. To measure the level of alignment with the IIRC framework, this study adopts the scoreboard developed by Marrone \& Oliva (2019). This scoreboard evaluates the presence within the integrated report of information related to the content elements and to the fundamental concepts (IIRC, 2013). Therefore, this scoreboard evaluates the presence of 10 elements: 8 content elements and 2 fundamental concepts. The two fundamental concepts are represented by the value creation process and by the capitals. The eight content elements are: governance, organizational overview and external environment, business model, strategy and resource allocation, outlook, performance, risks and opportunities, and basis of presentation. The scoreboard verifies the presence of qualitative, quantitative and monetary information within the reports. Therefore, this scoreboard assigns a score of 0 in the case of absence of a 
single element, a score of 1 in the case of, for the single element, only qualitative information was present, a score of 2 in the event that qualitative and quantitative information was present and, finally, a score of 3 in the case of the presence of qualitative, quantitative and monetary information. Therefore, the maximum score for each single element is 3 and the maximum score for an integrated report is 30 .

The independent variables of this study are represented by: firm size, firm profitability and financial leverage. In this work, firm size (SIZE) is calculated as natural logarithm of total assets and firm profitability is calculated through Return on Equity (ROE). Finally, financial leverage (FINLEV) is calculated as the ratio of the book value of debt over the book value of equity.

In order to increase the goodness of the regression model, we included some control variables.

First of all, we control for the industry environmental sensitivity (IES). This variable represents a dummy variable that assumes a value of 1 if the firm operates in a highly polluting sector and a score of 0 in the opposite case. Following Vitolla et al. (2019e) this study considers the following industries as environmentally sensitive: water utilities, construction, forest and paper products, logistics, automotive, aviation, chemical, mining, metal products, railroad, construction materials, energy, waste management, energy utilities and agriculture.

Secondly, following Vitolla et al. (2019e) we control for the age variable (AGE). This variable is calculated as the number of years since the establishment of the firm up to the end of 2019. It represents a proxy for the stability of the firm.

Finally, following Frias-Aceituno et al. (2013), we control for the board size (BOARDSIZE). This variable is calculated as the total number of the members on the board of directors.

To test the hypotheses, this work uses a regression model. Specifically, the model of analysis that this work proposes is reflected in the following equation:

$$
\text { IRAL }=\beta_{0}+\beta_{1} \text { SIZE }+\beta_{2} \text { ROE }+\beta_{3} \text { FINLEV }+\beta_{4} \text { IES }+\beta_{5} \text { AGE }+\beta_{6} \text { BOARDSIZE }+\varepsilon
$$

\section{Results}

\subsection{Descriptive Analysis and Correlation Analysis}

Table 1 shows descriptive statistics and correlation analysis. With reference to the first element, the interesting datum is represented by the average value of the dependent variable. In fact, the level of alignment with the IIRC framework (IRAL) has an average value equal to 22.17. Considering that the maximum obtainable score is 30 , it's clear that the integrated reports of the South African companies have on average a high level of compliance with the IIRC requirements.

With reference to the second element, the strongest correlation is found between integrated reporting alignment level and firm size (0.526). This value does not create multicollinearity problems (Farrar \& Glauber, 1967). We also controlled multicollinearity through the variance inflator factor (VIF) analysis. The results show the absence of multicollinearity since the VIFs ranged from a low value of 1.10 to a high value of 1.26 . VIFs less than 10 do not generate multicollinearity problems (Myers, 1990).

Table 1. Descriptive statistics and correlation analysis

\begin{tabular}{|c|c|c|c|c|c|c|c|c|c|c|c|c|}
\hline Variables & Mean & S.D. & IRAL & & SIZE & & ROE & FINLEV & IES & & AGE & BOARDSIZE \\
\hline IRAL & 22.17 & 3.01 & 1 & & & & & & & & & \\
\hline SIZE & 16.09 & 2.07 & 0.526 & $* * *$ & 1 & & & & & & & \\
\hline ROE & 19.01 & 19.63 & 0.413 & $* * *$ & 0.076 & & 1 & & & & & \\
\hline FINLEV & 12.51 & 7.12 & 0.490 & $* * *$ & 0.283 & $* *$ & 0.264 & $* *$ & & & & \\
\hline IES & 0.47 & 0.50 & 0.364 & $* * *$ & 0.011 & & 0.211 & 0.164 & 1 & & & \\
\hline AGE & 58.23 & 40.78 & 0.208 & $*$ & -0.051 & & 0.201 & 0.015 & 0.412 & $* * *$ & 1 & \\
\hline BOARDSIZE & 15.69 & 8.18 & 0.386 & $* * *$ & 0.119 & & 0.374 & $* * * \quad 0.206$ & * 0.168 & & 0.198 & 1 \\
\hline
\end{tabular}

Note. $n=65$. S.D. $=$ Standard Deviation. $\quad * * *=$ significant at the $1 \%$ level; $* *=$ significant at the $5 \%$ level; $*=$ significant at the $10 \%$ level.

\subsection{Results of the Hypotheses Tests}

Table 2 presents the findings of the regression model.

The value of the adjusted $\mathrm{R}^{2}$ is 0.338 , which indicates that the model can explain about $33.8 \%$ of the variance in the dependent variable. 
The hypothesis 1 (H1) suggested that firm size represents an antecedent of the level of alignment with the IIRC requirements. Specifically, the hypothesis stated that firm size positively influenced the level of compliance with the IIRC framework. The findings show a positive and significant association between firm size (SIZE) and the level of alignment with the IIRC framework (IRAL) at $p=0.000$. This result strongly supports the first hypothesis of this study and underlines how larger South African companies are more likely to prepare integrated reports more aligned with the IIRC framework.

The hypothesis $2(\mathrm{H} 2)$ suggested that firm profitability represents an antecedent of the level of alignment with the IIRC requirements. Specifically, the hypothesis stated that firm profitability positively influenced the level of compliance with the IIRC framework. The findings show a positive and significant association between firm profitability (ROE) and the level of alignment with the IIRC framework (IRAL) at $p=0.045$. This result supports the second hypothesis of this study and underlines how more profitable South African companies are more likely to prepare integrated reports more aligned with the IIRC framework.

The hypothesis 3 (H3) suggested that financial leverage represents an antecedent of the level of alignment with the IIRC requirements. Specifically, the hypothesis stated that financial leverage positively influenced the level of compliance with the IIRC framework. The findings show a positive and significant association between financial leverage (FINLEV) and the level of alignment with the IIRC framework (IRAL) at $p=0.009$. This result supports the third hypothesis of this study and underlines how South African companies with higher level of financial leverage are more likely to prepare integrated reports more aligned with the IIRC framework.

With reference to the control variables, the findings showed a positive impact of the industry environmental sensitivity (IES) and of the board size (BOARDSIZE) on the level of compliance with the IIRC framework respectively at $\mathrm{p}=0.022$ and $\mathrm{p}=0.090$.

Table 2. Hypotheses tests

\begin{tabular}{lllll}
\hline Variables & Coefficient & Standard error & p-value \\
\hline Cons & 8.536 & 2.074 & $0.000^{* * *}$ \\
SIZE & 0.614 & 0.129 & $0.000^{* * *}$ \\
ROE & 0.029 & 0.014 & $0.045^{* *}$ \\
FINLEV & 0.105 & 0.039 & $0.009^{* * *}$ \\
IES & 1.345 & 0.570 & $0.022^{* *}$ \\
AGE & 0.004 & 0.007 & 0.503 \\
BOARDSIZE & 0.059 & 0.034 & $0.090^{*}$ \\
N & 65 & & \\
Adj. $\mathrm{R}^{2}$ & 0.338 & & \\
\cline { 2 - 4 } & significant at the $5 \%$ level; $*=$ significant at the $10 \%$ level.
\end{tabular}

\section{Discussion and Conclusions}

This work demonstrates first of all that South African companies provide integrated reports characterized by a high level of alignment with the IIRC framework. Secondly, it shows how firm size, firm profitability and financial leverage positively impact the level of compliance with the IIRC requirements.

The first result was widely expected given the role played by South Africa in the process of creating the IIRC framework. South African companies seem to have decided to follow the instructions of the IIRC for the preparation of the integrated report. This was favoured by the simplicity and completeness of the IIRC requirements. The content and guiding principles defined by the IIRC are in fact able to allow companies to provide an integrated vision and to interconnect information relating to strategy, risks, performance, governance and future prospects. Therefore, a high level of compliance with the framework allows South African companies to provide investors and stakeholders with a complete and organic report that is easier to read and understand. Moreover, the higher level of compliance increases the level of standardization of reports, allowing investors and stakeholders to make comparisons between different companies by simply reading the integrated report. Finally, greater alignment with the framework simplifies readers' search for key content. These circumstances lead companies to provide integrated reports more in line with the IIRC framework.

The hypothesis test then confirmed a positive impact of firm size, profitability and financial leverage on the level of alignment of the integrated reports with the IIRC framework. 
Larger companies are more exposed to pressure from stakeholders. Thus, for larger companies, transparency is a way to mitigate pressures and reduce the risk of government interference in business activity. In this regard, greater alignment with the IIRC framework allows content standardization and therefore improves the readability and comprehensibility of the integrated report. Furthermore, greater alignment favours the comparison between the different business realities. Also this element is able to improve the understanding of the corporate dynamics of the stakeholders. Therefore, these circumstances explain the reasons why larger companies are more likely to provide integrated reports more aligned with the IIRC framework.

The greater level of comparison between the different companies connected to a greater compliance with the IIRC framework is able to explain also the reasons for which the most profitable companies provide integrated reports more aligned with the IIRC requirements. The most profitable companies are in fact interested in showing their performance and therefore are interested in the possibility of creating high comparison opportunities with competitors. In this perspective, one solution is the greater alignment with the IIRC framework.

Finally, for the most indebted companies a clear disclosure represents a means to mitigate risks and show the ability to fulfil all financial obligations. Therefore, the greater alignment with the IIRC framework, improving the comprehensibility and readability of the integrated reports and favouring the search for key contents, allows companies with high levels of financial leverage to reduce risks and to clearly show their abilities to fulfilment of financial obligations.

This study contributes to the literature in different ways. First of all, it increases knowledge of the dynamics connected to integrated reporting in the South African context, showing how companies operating in the country provide integrated reports with high levels of alignment with the IIRC requirements. Secondly, this study increases the knowledge of the determinants of the compliance level with the IIRC framework. In this perspective, this study shows how firm size, firm profitability and financial leverage positively affect the level of alignment.

This work provides important managerial implications. The managers of larger, more profitable and more indebted companies should increase the level of alignment with the IIRC framework. In fact, a high level of alignment guarantees numerous benefits to companies connected primarily to a reduction in pressures and greater legitimacy. Furthermore, greater alignment makes it possible to show corporate performance more clearly and to show the ability of companies to meet their financial obligations.

However, this work has a methodological limitation. In fact, it is based on a cross-section instead of a panel analysis, due to a limited variability of the dependent variable. However, this limitation represents a starting point for future research. In fact, in the future, researchers could test the results of this work through longitudinal analyses. Furthermore, future studies could analyse the impact on the level of alignment with the IIRC framework of additional variables related to corporate governance or to the characteristics of the country in which companies operate.

\section{References}

Abdullah, W. A. W., Percy, M., \& Stewart, J. (2015). Determinants of voluntary corporate governance disclosure: Evidence from Islamic banks in the Southeast Asian and the Gulf Cooperation Council regions. Journal of Contemporary Accounting \& Economics, 11(3), 262-279. https://doi.org/10.1016/j.jcae.2015.10.001

Adams, C. A., Hill, W. Y., \& Roberts, C. B. (1998). Corporate social reporting practices in Western Europe: legitimating corporate behaviour? The British accounting review, 30(1), 1-21. https://doi.org/10.1006/bare.1997.0060

Andrikopoulos, A., Samitas, A., \& Bekiaris, M. (2014). Corporate social responsibility reporting in financial institutions: Evidence from Euronext. Research in International Business and Finance, 32, 27-35. https://doi.org/10.1016/j.ribaf.2014.02.001

Berwick, G. (2007). The Executives Guide to Insurance and Risk Management: Taking Control of Your Insurance Programme. QR Consulting.

Bezuidenhout, A., Fig, D., Hamann, R. \& Omar, R., (2007). Political Economy. In Fig, D. editor, Staking Their Claims (Eds.), Corporate Social and Environmental Responsibility in South Africa. Scottsville: University of KwaZulu-Natal Press.

Bhasin, M. L., Makarov, R., \& Orazalin, N. (2012). Determinants of voluntary disclosure in the banking sector: An empirical study. International Journal of Contemporary Business Studies, 3(3), 60-71.

Cerf, A. R. (1961). Corporate reporting and investment decisions. Public Accounting Research Program. Institute of Business and Economic Research, University of California. 
Clarke, J., \& Gibson-Sweet, M. (1999). The use of corporate social disclosures in the management of reputation and legitimacy: a cross sectorial analysis of UK Top 100 Companies. Business Ethics: A European Review, 8(1), 5-13. https://doi.org/10.1111/1467-8608.00120

Clayton, A. F., Rogerson, J. M., \& Rampedi, I. (2015). Integrated reporting vs. sustainability reporting for corporate responsibility in South Africa. Bulletin of Geography. Socio-economic series, 29(29), 7-17. https://doi.org/10.1515/bog-2015-0021

Dowling, J., \& Pfeffer, J. (1975). Organizational legitimacy: Social values and organizational behavior. Pacific sociological review, 18(1), 122-136. https://doi.org/10.2307/1388226

Eccles, R. G., \& Krzus, M. P. (2010). One report: Integrated reporting for a sustainable strategy. John Wiley \& Sons.

Eccles, R. G., Serafeim, G., \& Armbrester, P. (2012). Integrated Reporting in South Africa. Boston: Harvard Business School.

Ernst \& Young (2012). Excellence in Integrated Reporting Awards 2012. In Ernst \& Young: Quality in everything we do. $\quad$ Retrieved from http://www.ey.com/ZA/en/Services/Specialty-Services/Climate-Change-and-Sustainability-Services/2012_ EIR_main-page

Farrar, D. E., \& Glauber, R. R. (1967). Multicollinearity in regression analysis: the problem revisited. The Review of Economic and Statistics, 92-107. https://doi.org/10.2307/1937887

Fifka, M. S. (2013). Corporate responsibility reporting and its determinants in comparative perspective-a review of the empirical literature and a meta-analysis. Business strategy and the environment, 22(1), 1-35. https://doi.org/10.1002/bse.729

Frias-Aceituno, J. V., Rodriguez-Ariza, L., \& Garcia-Sanchez, I. M. (2013). The role of the board in the dissemination of integrated corporate social reporting. Corporate Social Responsibility and Environmental Management, 20(4), 219-233. https://doi.org/10.1002/csr.1294

Frías-Aceituno, J. V., Rodríguez-Ariza, L., \& Garcia-Sánchez, I. M. (2014). Explanatory factors of integrated sustainability and financial reporting. Business Strategy and the Environment, 23(1), 56-72.

Gray, R., Kouhy, R., \& Lavers, S. (1995). Corporate social and environmental reporting: a review of the literature and a longitudinal study of UK disclosure. Accounting, Auditing \& Accountability Journal, 8(2), 47-77. https://doi.org/10.1108/09513579510146996

GRI (Global Reporting Initiative) (2013). Carrots and Sticks: Sustainability Reporting Policies Worldwide Today's Best Practice, Tomorrow's Trends, Amsterdam: Global Reporting Initiative.

Hackston, D., \& Milne, M. J. (1996). Some determinants of social and environmental disclosures in New Zealand companies. Accounting, Auditing \& Accountability Journal, 9(1), 77-108. https://doi.org/10.1108/09513579610109987

IIRC (International Integrated Reporting Council) (2013). International <IR $>$ Framework. Retrieved from http://www.integratedreporting.org

IoDSA (Institute of Directors Southern Africa) (2002). King Report on Corporate Governance for South Africa. Johannesburg: Institute of Directors in Southern Africa.

Jensen, J. C., \& Berg, N. (2012). Determinants of traditional sustainability reporting versus integrated reporting. An institutionalist approach. Business Strategy and the Environment, 21(5), 299-316. https://doi.org/10.1002/bse.740

Jensen, M. C., \& Meckling, W. H. (1976). Theory of the firm: Managerial behavior, agency costs and ownership structure. Journal of financial economics, 3(4), 305-360. https://doi.org/10.1016/0304-405X(76)90026-X

Kahl, A., \& Belkaoui, A. (1981). Bank annual report disclosure adequacy internationally. Accounting and Business Research, 11(43), 189-196. https://doi.org/10.1080/00014788.1981.9729700

Khan, H. U. Z. (2010). The effect of corporate governance elements on corporate social responsibility (CSR) reporting: Empirical evidence from private commercial banks of Bangladesh. International Journal of Law and Management, 52(2), 82-109. https://doi.org/10.1108/17542431011029406

Knox, S., Maklan, S., \& French, P. (2005). Corporate social responsibility: Exploring stakeholder relationships and programme reporting across leading FTSE companies. Journal of business ethics, 61(1), 7-28. 
https://doi.org/10.1007/s10551-005-0303-4

Lambert, J. (2005). A New Framework for Business: Introduction. The Sustainable Enterprise. Sterling: Kogan Page Limited.

Malone, D., Fries, C., \& Jones, T. (1993). An empirical investigation of the extent of corporate financial disclosure in the oil and gas industry. Journal of Accounting, Auditing \& Finance, 8(3), 249-273. https://doi.org/10.1177/0148558X9300800306

Marrone, A. \& Oliva, L. (2019). Measuring the Level of Integrated Reporting Alignment with the $<I R>$ Framework. International Journal of Business and Management, 14(12), 110-120. https://doi.org/10.5539/ijbm.v14n12p110

Marx, B., \& Van Der Watt, A. (2011). Sustainability and integrated reporting: an analysis of the audit committee's oversight role. Journal for New Generation Sciences, 9(2), 56-71.

Myers, R. H. (1990). Classical and modern regression with applications. Second edition. Belmont, CA: Duxbury.

Ness, K. E., \& Mirza, A. M. (1991). Corporate social disclosure: A note on a test of agency theory. The British Accounting Review, 23(3), 211-217. https://doi.org/10.1016/0890-8389(91)90081-C

Raimo, N., Zito, M., \& Caragnano, A. (2019). Does national culture affect integrated reporting quality? A focus on GLOBE dimensions. In 9th International Symposium on Natural Resources Management, Zaječar, Serbia.

Rensburg, R., \& Botha, E. (2014). Is integrated reporting the silver bullet of financial communication? A stakeholder perspective from South Africa. Public Relations Review, 40(2), 144-152. https://doi.org/10.1016/j.pubrev.2013.11.016

Reverte, C. (2009). Determinants of corporate social responsibility disclosure ratings by Spanish listed firms. Journal of business ethics, 88(2), 351-366. https://doi.org/10.1007/s10551-008-9968-9

SAICA (The South African Institute of Chartered Accountants) (2013). Summary of report on governance for South Africa - King III 2009. The South African Institute of Chartered Accountants. Retrieved from http://www.auditor.co.za/Portals/23/king\%20111\%20saica.pdf

SAICA (The South African Institute of Chartered Accountants) 2012: The Integrated Reporting Committee in South Africa. Retrieved from http://www.sustainabilitysa.org/IntegratedReporting/TheIntegratedReportingCommitteeofSouthAfrica.aspx

Schulschenk, J. (2012). Interview summary report. Pretoria: Ernst and Young South Africa.

Sharif, M., \& Rashid, K. (2014). Corporate governance and corporate social responsibility (CSR) reporting: an empirical evidence from commercial banks (CB) of Pakistan. Quality \& Quantity, 48(5), 2501-2521. https://doi.org/10.1007/s11135-013-9903-8

Sierra-García, L., Zorio-Grima, A., \& García-Benau, M. A. (2015). Stakeholder engagement, corporate social responsibility and integrated reporting: An exploratory study. Corporate Social Responsibility and Environmental Management, 22(5), 286-304. https://doi.org/10.1002/csr.1345

Singhvi, S. S., \& Desai, H. B. (1971). An empirical analysis of the quality of corporate financial disclosure. The Accounting Review, 46(1), 129.

Siregar, S. V., \& Bachtiar, Y. (2010). Corporate social reporting: empirical evidence from Indonesia Stock Exchange. International Journal of Islamic and Middle Eastern Finance and Management, 3(3), 241-252. https://doi.org/10.1108/17538391011072435

Sonnenberg, D., \& Hamann, R. (2006). The JSE Socially Responsible Investment Index and the state of sustainability reporting in South Africa. Development Southern Africa, 23(2), 305-320. https://doi.org/10.1080/03768350600707942

Udayasankar, K. (2008). Corporate social responsibility and firm size. Journal of business ethics, 83(2), 167-175. https://doi.org/10.1007/s10551-007-9609-8

Vitolla, F., \& Raimo, N. (2018). Adoption of integrated reporting: Reasons and benefits-A case study analysis. International Journal of Business and Management, 13(12), 244-250. https://doi.org/10.5539/ijbm.v13n12p244

Vitolla, F., Raimo, N., \& De Nuccio, E. (2018). Integrated Reporting: Development and State of Art - The Italian Case in the International Context. International Journal of Business and Management, 13(11), 233-240. https://doi.org/10.5539/ijbm.v13n11p233 
Vitolla, F., Raimo, N., \& Rubino, M. (2019a). Intellectual Capital Disclosure and Firm Performance: An Empirical Analysis Through Integrated Reporting. In 7th International OFEL Conference, Dubrovnik, Croatia.

Vitolla, F., Raimo, N., \& Rubino, M. (2019b). Appreciations, criticisms, determinants, and effects of integrated reporting: A systematic literature review. Corporate Social Responsibility and Environmental Management, 26(2), 518-528. https://doi.org/10.1002/csr.1734

Vitolla, F., Raimo, N., Rubino, M., \& Garzoni, A. (2019d). How pressure from stakeholders affects integrated reporting quality. Corporate Social Responsibility and Environmental Management. https://doi.org/10.1002/csr.1850

Vitolla, F., Raimo, N., Rubino, M., \& Garzoni, A. (2019e). The impact of national culture on integrated reporting quality. A stakeholder theory approach. Business Strategy and the Environment. https://doi.org/10.1002/bse.2332

Vitolla, F., Salvi, A., Raimo, N., Petruzzella, F., \& Rubino, M. (2019c). The impact on the cost of equity capital in the effects of integrated reporting quality. Business Strategy and the Environment. https://doi.org/10.1002/bse.2384

Wallace, R. O., \& Naser, K. (1995). Firm-specific determinants of the comprehensiveness of mandatory disclosure in the corporate annual reports of firms listed on the stock exchange of Hong Kong. Journal of Accounting and Public policy, 14(4), 311-368. https://doi.org/10.1016/0278-4254(95)00042-9

Watts, R., \& Zimmerman, J. (1986). Positive Accounting Theory. Prentice Hall, Englewood Cliffs, NJ.

Wingard, H. C., \& Vorster, Q. (2001). Financial performance of environmentally responsible South African listed companies. Meditari Accountancy Research, 9(1), 313-332. https://doi.org/10.1108/1022252920010017

\section{Copyrights}

Copyright for this article is retained by the author(s), with first publication rights granted to the journal.

This is an open-access article distributed under the terms and conditions of the Creative Commons Attribution license (http://creativecommons.org/licenses/by/4.0/). 